УДК 620.197

В.І.Воробйова /к.т.н./, О.Е. Чигиринець /д.Т.н./

Національний технічний університет «Київський політехнічний інститут імені Ігоря Сікорського», м. Київ, Україна

\title{
ПРОТИКОРОЗІЙНІ ВЛАСТИВОСТІ НАНОРОЗМІРНИХ ПЛІВОК, УТВОРЮВАНИХ ЛЕТКИМИ ОРГАНІЧНИМИ СПОЛУКАМИ РОСЛИННОГО ПОХОДЖЕННЯ
}

\author{
V.I. Vorobyova /Ph. D./, \\ O.E.Chyhyrynets /Dr. Sci. (Tech.)/
}

National Technical University of Ukraine "Igor Sikorsky Kyiv Polytechnic Institute", Kyiv, Ukraine

\section{CORROSION PROPERTIES OF NANOSIZED FILMS FORMED BY VOLATILE ORGANIC COMPOUNDS OF VEGETABLE ORIGIN}

Мета. Розробка екологічно безпечного леткого інгібітора для захисту від атмосферної корозії вуглецевої сталі на основі рослинних відходів, а саме вичавок промислової переробки абрикоса.

Методика. Протикорозійну ефективність летких фракиій інгібітора оцінено методами прискорених корозійних випробувань. Морфологію та товщину утворених плівок вивчено за допомогою скануючої атомно-силової мікроскопї̈.

Результати. Встановлено, що високо захисна плівка летких органічних сполук вичавок абрикоса товщиною до 250 нм формується не менше, ніж 48 годин, забезпечуючи гальмування анодної і катодної реакцій корозії в умовах періодичної конденсації вологи. В оптимальній концентрації летких сполук забезпечується повний захист металу від корозії.

Наукова новизна. Показано, що вичавки промислової переробки абрикоса є сировиною для створення ефективного екологічно безпечного інгібітору для тимчасового захисту металопрокату від атмосферної корозї. Визначено особливості процесу формування захисної плівки та ї̈ товщину.

Практична значимість. Результати свідчать про ефективність використання пакувальних матеріалів з вітчизняними леткими інгібіторами на основі рослинних відходів (вичавок абрикосу) для використання виробниками металопрокату з метою підвищення конкурентоспроможності металопродукиії.

Ключові слова: леткий інгібітор атмосферної корозї̈, тимчасовий захист від корозії, нанорозмірна плівка, рослинні відходи.

DOI: 10.34185/0543-5749.2019-3-4-7-13

Вступ. Сучасні технології виробництва передбачають виробництво та доставку продукції в якісному вигляді, що сприяє значному підвищенню продажної вартості виробів. 3 підвищенням конкурентної ситуації на світовому ринку промисловими металургійними виробниками все більше уваги приділяється зовнішньому вигляду металопродукції. Одним із важливих чинників цього явища $є$ той факт, що користувач металургійної продукції зацікавлений в отри- манні продукту без корозійних ушкоджень, до того ж не використовуючи додаткових витрат на очищення та підготовку металевої поверхні для подальшого використання в технологічному процесі.

Одним із відносно недорогих сучасних способів доставки до покупця металопрокату в неушкодженому вигляді є використання пакувальних матеріалів 3 антикорозійними властивостями, які дозволяють зберігати продукцію на час

(C) Воробйова В.І., Чигиринець О.Е., 2019 г. 
транспортування або тимчасового зберігання без корозійних ушкоджень. Такими способом поставляють не тільки готові до використання вироби, наприклад двигуни та інші види техніки, але й напівфабрикати, такі як метизні вироби, різні види прокату - лист, труби тощо.

Основним компонентом пакувальних матеріалів є леткі інгібітори атмосферної корозії (ЛІАК), які вводять як в папір, так і в поліетиленову плівку. Основною перевагою їх використання є формування нанорозмірних плівок (покриттів), що не потребують розконсервації та не змінюють функціональні властивості поверхні виробів [1 - 5]. До найбільш широко відомих ЛІАК відносяться хімічно синтезовані органічні і неорганічні сполуки або їх суміші на основі амінів тощо. Однак, висока вартість реагентів, багатостадійність в технології їх синтезу, а також екологічна небезпечність викликає нагальну потребу в розробці альтернативних екологічно безпечних і біодеградабельних або так званих «зелених» ЛІАК. Особливо актуальним це питання $\epsilon$ для українського виробника хімічної продукції, оскільки сировинні хімічні реагенти взагалі в країні не виробляються, а отже виробництво летких інгібіторів корозії на таких реагентах є нерентабельним.

Відповідно до сучасних тенденцій розвитку раціонального природокористування все більша увага приділяється повторному використанню відходів рослинної сировини для отримання різного типу продуктів. Це $є$ актуальним і в напрямку створення інгібіторів корозії. На основі досліджень широкого переліку рослинних матеріалів авторами роботи було встановлено [6 - 7], що леткі екстрактивні сполуки шроту ріпаку, шишок хмелю, трави полину, шкаралупи волоського горіха та інші володіють певним рівнем протикорозійних властивостей. У той же час, серед розмаїття вторинних сировинних ресурсів перспективним $€$ використання відходів агропромислового комплексу, а саме вичавок плодово-ягідних і плодоовочевих культур. Так, в Україні, вичавки абрикоса складають близько $20 \%$ від усього обсягу переробки плодовоягідних культур, а утворені відходи, серед яких в основному шкірка та в меншій кількості низькомолекулярні фрагменти целюлози, зазвичай використовують як добриво або корм худобі. Водночас ці рослинні відходи мають унікальний хімічний склад, який робить цю сировину надзвичайно перспективною щодо отримання біологічно активних добавок [8] а також органічних сполук 3 високою хімічною активністю. Відомим $\epsilon$ і наявність в цих відходах летких органіч- них сполук [9-10].

У зв'язку з вищесказаним актуальним є дослідження можливості створення ЛІАК з високими захисними властивостями проти атмосферної корозії на основі вичавок, утворених в процесі промислової переробки абрикоса, визначення особливостей процесу формування на поверхні сталі плівок на основі летких органічних сполук та їх властивостей щодо тимчасового захисту металу від атмосферної корозії.

Методика досліджень. Корозійні і електрохімічні дослідження проводили на зразках сталі Ст 3 з наступним компонентним складом (\%): 0,20 C, 0,43 Mn, 0,55 Si, 0,016 S, 0,02 P інше$\mathrm{Fe}$ Перед дослідженнями зразки Ст3 (розміром 50 x 20 × 1,5 мм) зачищали наждачним папером різної зернистості $(1 / 0,2 / 0,3 / 0)$, знежирювали i витримували в ексикаторі протягом 1 доби. Екстракт вичавок абрикоса готували шляхом настоювання попередньо подрібненої рослинної сировини в розчині ізопропілового спирту протягом 48 годин при співвідношенні тверда частина: екстрагент - $1: 10$ з подальшим фільтруванням через папір. Далі за допомогою роторного випарювача отримували сухий залишок екстракту, який розчиняли у різній концентрації в ізопропіловому спирті та використовували як ЛІАК.

Оцінку протикорозійної ефективності ЛІАК оцінювали методом прискорених випробувань в умовах періодичної конденсації вологи. Для конденсації використовували дистильовану воду. Зразки розміщували в герметичній посудині 3 водним розчином електроліту і ємністю 3 летким інгібітором в термокамері, в якій підтримували режим періодичної конденсації вологи (один цикл випробувань -8 годин при $40{ }^{\circ} \mathrm{C}$ i 16 год при $\left.25^{\circ} \mathrm{C}\right)$. Тривалість випробувань становила 21 добу.

Загальну оцінку ефективності протикорозійного захисту здійснювали за швидкістю корозії стали, а також за зовнішнім станом зразків в процесі і після випробувань відповідно до вимог ГОСТ 9.905-82 і ГОСТ 9.509-89.

В роботі оцінено інгібуючі властивості ЛІАК шляхом вивчення процесу протікання анодної та катодної реакцій корозії сталі в $0,5 \mathrm{M}$ розчині $\mathrm{Na}_{2} \mathrm{SO}_{4}$, що моделює умови атмосферної корозії. Поляризаційні корозійні дослідження проводили на армованих в тефлон циліндричних зразках з використанням потенціостата ПИ-50-1 i програматора ПР-8. Швидкість розгортки потенціалу становила $25 \mathrm{mB} /$ хв. Потенціал сталевого електрода вимірювали відносно насиченого хлоридсрібного електрода і перераховували на 
нормальну водневу шкалу; допоміжним електродом слугував платиновий електрод.

Морфологію поверхні зразків металу без плівки і після формування плівки ЛІАК вивчали за допомогою скануючого електронного мікроскопа FEI E-SEM XL 30 (Детектування вторинних електронів) і методом скануючої атомносилової мікроскопії ( NT-MDT Solver P47-PRO).
Виклад основного матеріалу. Прискорені випробування показали високий ступінь інгібуючої ефективності ЛІАК за умови конденсації вологи (табл. 1). Ефективність інгібіторного захисту при конденсації дистильованої води склала близько 97,6 \%. Встановлено, що ступінь захисту поступово підвищується зі збільшенням концентрації інгібітора в діапазоні від 15 д до $97 \%$.

Таблиця 1. Швидкість корозії і ступінь захисту зразків з захисною плівкою, сформованою з парової фази ЛІАК на поверхні сталі Ст 3, після прискорених випробувань в умовах періодичної конденсації вологи протягом 21 доби

\begin{tabular}{|c|c|c|}
\hline Концентрація інгібітора, мг/л & Швидкість корозії, $\Gamma^{\cdot} \mathrm{M}^{-2} \cdot$ год $^{-1}$ & Ступінь захисту $(\mathrm{Z}), \%$ \\
\hline 10 & 0,1585 & 15,94 \\
\hline 20 & 0,0912 & 51,46 \\
\hline 30 & 0,0610 & 67,52 \\
\hline 40 & 0,0526 & 71,98 \\
\hline 50 & 0,0382 & 79,67 \\
\hline 60 & 0,0306 & 88,90 \\
\hline 70 & 0,0186 & 91,00 \\
\hline 80 & 0,0121 & 93,71 \\
\hline 100 & 0,0045 & - \\
\hline Без інгібітора & 0,1879 & \\
\hline
\end{tabular}

Швидкість процесу формування захисної плівки ЛІАК і їі інгібуючі властивості суттєво залежать як від хімічної природи складових композиції леткого інгібітора, так і від умов формування плівки $[11-12]$. Більш ранніми дослідженнями встановлено, що ізопропанольний екстракт вичавок абрикоса містить широкий перелік органічних сполук (альдегіди, кетони, монотерпенові феноли, спирти та ін) [8], тиск насиченої пари яких варіюється i, як наслідок, обумовлює поступове пролонговане формування плівки на поверхні сталі. У зв'язку з вищесказаним доцільним є дослідження кінетики формування захисної плівки на поверхні сталі.
Встановлено, що з часом швидкість корозії сталі в газопаровій фазі екстракту зменшується, а його інгібуюча ефективність зростає при збільшенні часу формування захисної плівки (табл. 2). Так, встановлено, що ступінь захисту залежить від часу формування поверхневої плівки в летких фракціях екстракту вичавок абрикоca, і знаходиться в межах 27,69 - 93,01\%. Отримані результати свідчать, що мінімально необхідним часом для формування захисної плівки є витримка сталевих зразків в атмосфері екстракту протягом не менше як 48 годин. Слід зазначити, що обробка зразків ізопропанолом не впливає на швидкість атмосферної корозії металу.

Таблиця 2. Швидкість корозії і ступінь захисту зразків в залежності від часу формування плівки в паровій фазі ЛІАК (концентрація 100 мг/л) на поверхні сталі Ст 3, після прискорених випробувань в умовах періодичної конденсації вологи протягом 21 доби

\begin{tabular}{|c|c|c|}
\hline Час формування плівки, год & Швидкість корозії, $\Gamma^{\cdot} \mathbf{M}^{-2} \cdot$ год $^{-1}$ & Ступінь захисту $(\mathrm{Z}), \%$ \\
\hline 12 & 0,1359 & 27,69 \\
\hline 24 & 0,0929 & 50,55 \\
\hline 30 & 0,0776 & 58,67 \\
\hline 35 & 0,0564 & 69,95 \\
\hline 40 & 0,0457 & 75,64 \\
\hline 48 & 0,0186 & 91,00 \\
\hline 60 & 0,0148 & 92,08 \\
\hline 72 & 0,0131 & 93,01 \\
\hline Без інгібітора & 0,1879 & - \\
\hline
\end{tabular}


Дослідження впливу сформованої плівки ЛІАК на швидкість парціальних електродних процесів анодного окиснення сталі і катодного відновлення молекулярного кисню в $0,5 \mathrm{M}$ розчині $\mathrm{Na}_{2} \mathrm{SO}_{4}$ показали, що швидкість анодних процесів значно вища, ніж швидкість катодних процесів (рис. 1).

У фоновому розчині $0,5 \mathrm{M} \mathrm{Na}_{2} \mathrm{SO}_{4}$ стаціонарний електродний потенціал сталі становить $\mathrm{E}_{\mathrm{cт}}=-0,45 \mathrm{~B}$. За умови анодної поляризації електроду спостерігається його активне розчинення. На катодній кривій в цьому розчині присутня ділянка граничного дифузійного струму.
Саме цей процес зазвичай є лімітуючою стадією корозійного процесу в умовах атмосфери. При використанні ЛІАК спостерігається зміщення стаціонарного потенціалу в бік більш позитивних значень, вірогідно, за рахунок гальмування як анодного, так і катодного корозійних процесів. Поступове збільшення часу формування плівки від 12 до 72 годин призводить до збільшення інгібуючої ефективності сформованої захисної плівки, на що вказує зменшення анодного струму розчинення і значення граничного дифузійного струму на катодній поляризаційній кривій.

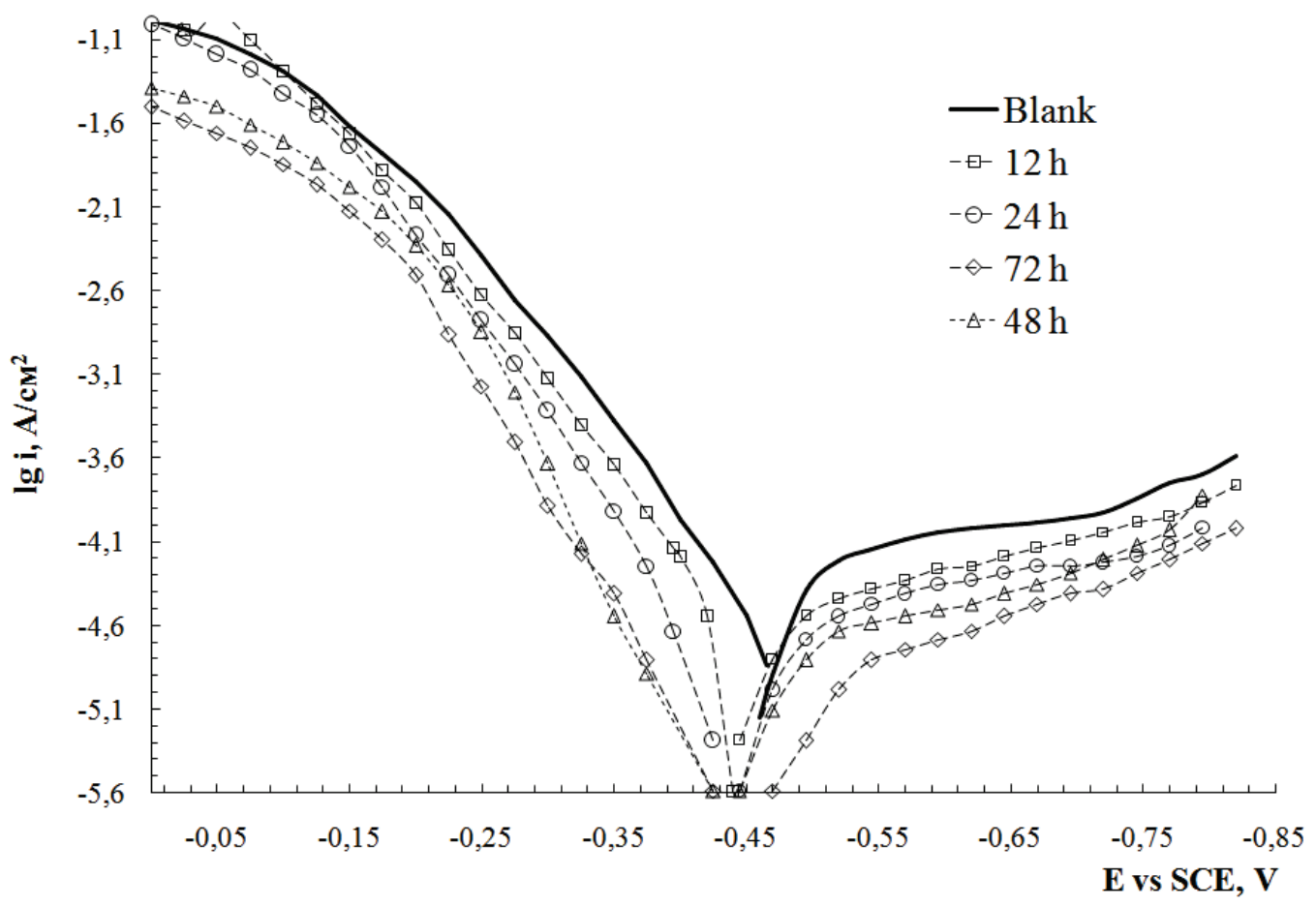

Рис. 1. Поляризаційні анодні та катодні криві на сталі Ст 3 в розчині $0,5 \mathrm{M} \mathrm{Na}_{2} \mathrm{SO}_{4}$ без (blank) і з плівкою, отриманою після формування протягом $12,24,48,72$ годин в паровій фазі екстракту вичавок абрикоса

Для характеристики морфології поверхні плівки, сформованої на поверхні сталі при обробці леткими сполуками вичавок абрикоса проведено мікроскопічні дослідження. Зображення механічно підготовленої сталевої поверхні (рис. 2,a) та після 24, 40 і 48 годин формування плівки (рис. 2, b, c, d) вказують, що на поверхні сталевих зразків після експонування протягом двох діб в атмосфері летких сполук екстракту сформувалася захисна плівка, морфологія якої стає більш суцільною i «заповненою» у міру збільшення часу формування.

Методом зондової атомно-силової мікрос- копії досліджено мікрорельєф поверхні сталевих зразків після 12 і 48 годин плівкоутворення в атмосфері екстракту вичавок абрикоса (рис. 3). Отримані результати підтверджують раніше отримані результати масометричних $\mathrm{i}$ електрохімічних досліджень, які свідчать, що інгібуючі властивості захисних шарів підвищуються зі збільшенням часу формування плівки. Так, для поверхні сталі, обробленої протягом 24 годин значення середньої арифметичної шорсткості $\left(\mathrm{R}_{\mathrm{a}}\right)$ знаходиться в діапазоні 123,07 - 195,43 нм, а середня глибина шорсткості $\left(\mathrm{R}_{\mathrm{z}}\right)$ - в діапазоні 629,31 809,10 нм. Для поверхні, модифікованої про- 
тягом 48 годин, значення $\mathrm{R}_{\mathrm{a}}$ знаходиться в діапазоні 104,75 - 171,35 нм, a $\mathrm{R}_{\mathrm{z}}-$ між 510,85 - 580,90 нм.

Аналізом результатів, отриманих методом

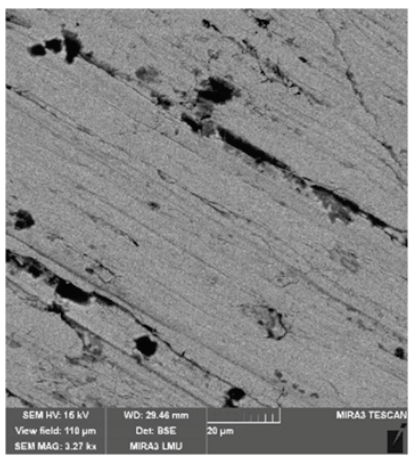

(a)

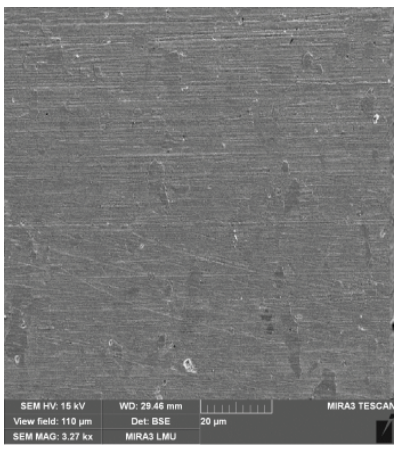

(b) атомно-силової мікроскопії встановлено товщину захисної плівки летких сполук екстракту вичавок абрикосу, яка складає не більше як $250 \mathrm{HM}$

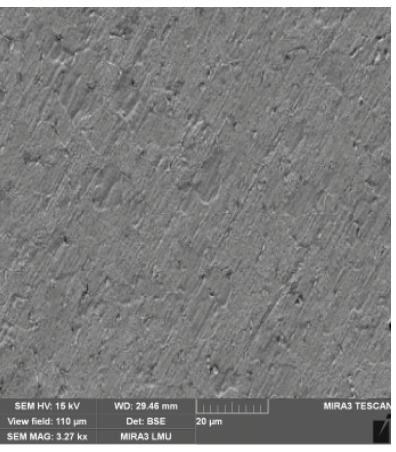

(c)

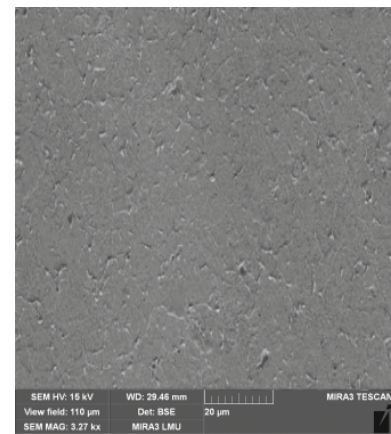

(d)

Рис.2. Морфологія поверхні сталевих зразків: а) без плівки (після механічної обробки); після формування плівки в протягом 24 (b), 40 (c), 48 (d) годин в газопаровій атмосфері екстракту вичавок абрикоса

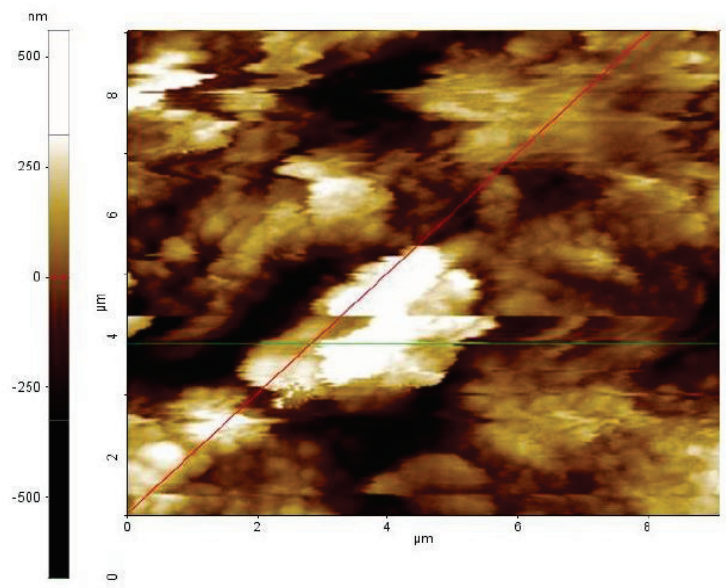

(a)

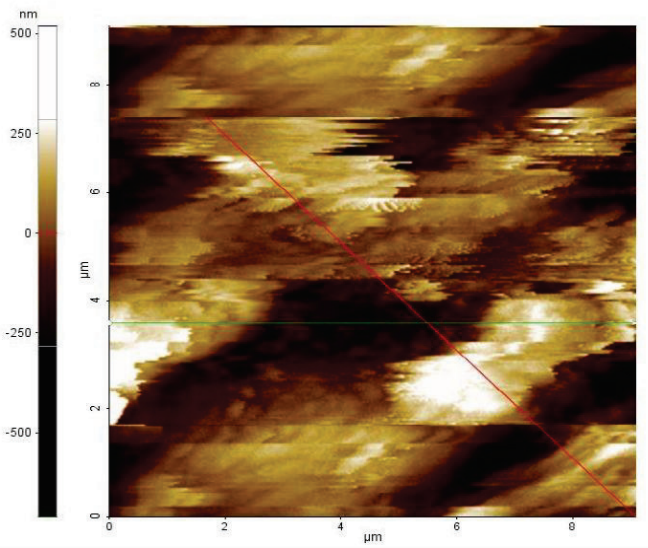

(c)

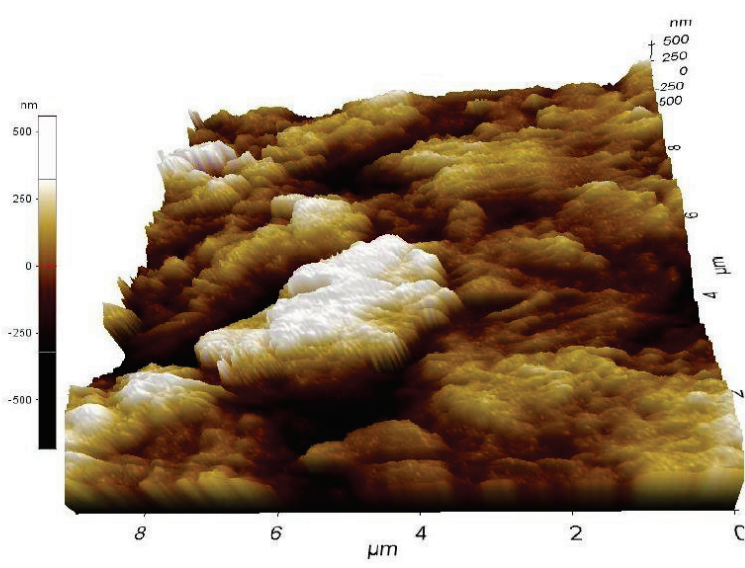

(b)

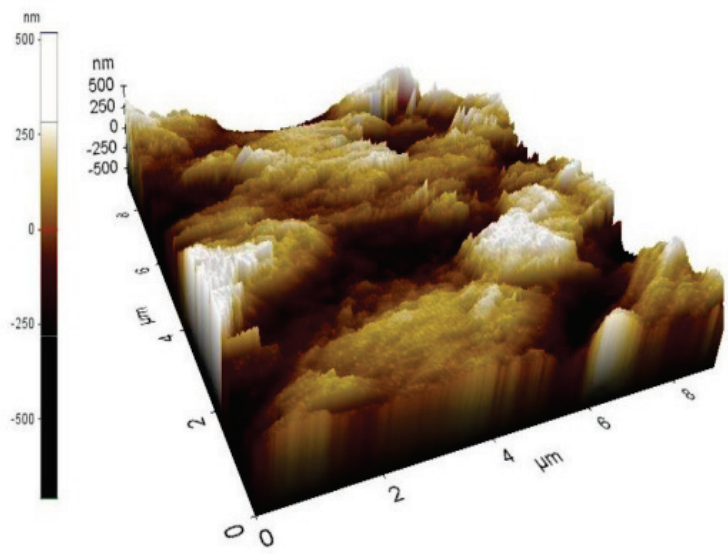

(d)

Рис. 3. 2D i 3D ACM-зображення поверхні сталі після 12 год (a), (b) і 48 год (c), (d) плівкоутворювання в газопаровій атмосфері ізопропанольного екстракту вичавок абрикоса 
Висновки. Отримані результати прискорених корозійних випробувань, електрохімічних досліджень та вивчення морфології утворених плівок на поверхні сталі свідчать, що досліджувані леткі сполуки вичавок абрикоса формують захисний наношар товщиною до 250 нм на поверхні сталі, ефективно гальмуючи доступ кисню до поверхні металу, тим самим забезпечуючи зниження швидкості корозійних процесів. Промислові вичавки абрикоса $є$ перспективною сировиною для створення високоефективного плівкоутворювального леткого інгібітора корозії.

\section{Бібліографічний список}

1. Da-Quan, Z., Li-Xin, G., Guo-Ding, Z. Self-assembled urea-amine compound as vapor phase corrosion inhibitor for mild steel. Surface and Coatings Technology. 2010. Vol. 204. P. 16461650.

2. Nazeera Banu, V.R., Rajendran, S.S., Senthil, K. Investigation of the inhibitive effect of Tween 20 self-assembling nanofilms on corrosion of carbon steel. Journal of Alloys and Compounds. 2016. Vol. 675. P. 139-148.

3. Designing and fabricating of single and double alkyl-chain indazole derivatives selfassembled monolayer for corrosion inhibition of copper / Yujie, Q. et. al. Corrosion Science. 2018. Vol. 140. P. 111-121.

4. Hosseinpoura, S., Göthelidb, M., Leygrafa, C., Magnus, J. C. Self-assembled monolayers as inhibitors for the atmospheric corrosion of copper induced by formic acid: a comparison between hexanethiol and hexaneselenol. Journal of the Electrochemical Society. 2014. Vol. 161, No. 1. P. 50-56.

5. Thiol self-assemble layer as inhibitor to protect B10 from seawater corrosion / Feng-ling, X. et. al. Progress in Organic Coatings. 2016. Vol. 97. P. 82-90. DOI: https://doi.org/10.1016/j.porgcoat. 2016.03.022.

6. Chyhyrynets' O. E., Vorob'iova V. I. Anticorrosion Properties of the Extract of Rapeseed Oil Cake as a Volatile Inhibitor of the Atmospheric Corrosion of Steel. Materials Science. 2013. Vol. 49, No. 3. P. 318-325.

7. Протикорозійні властивості шишок хмелю/ Чигиринець О. Е. та інш. Наукові вісті «KПI». 2012. № 2. С. 137-148.

8. Вивчення компонентного складу та протикорозійної ефективності продуктів переробки абрикоса (PrunusarmeniacaL.) / Воробйова В. I. та інш. Технічні науки та технології. 2018. № 3 (13). C. 240-250.

9. Apricot (Prunusarmeniaca L.) fruitquality attributes and phytochemical sunder different cropload/ Roussos, P. A. et. al. Scientiahorticulturae. 2011. Vol. 129. P. 472.

10. Gokbulut, I., Karabulut, I. SPME-GC-MS detection of volatile compounds in apricot varieties. FoodChemistry. 2012. Vol. 132. P. 1098.

11. Rajendran, S., Rathish, R. J., Prabha, S. S. Self-assembling nano films on metal surface as corrosion inhibitors. Advanced Materials Proceedings. 2017. Vol. 2, No. 9. P. 596-601.

12. Shubha, H.N., Venkatesha, T.V., Pavithra, M.K., Punith Kumar, M.K. Surface modification of mild steel by a self-assembled cetyl-trimethyl ammonium bromide (CTAB) monolayer: Evaluation of its corrosion protection property. Progress in Organic Coatings. 2016. Vol. 90. P. 267-276.

\section{References}

1. Da-Quan, Z., Li-Xin, G., \& Guo-Ding, Z. (2010). Self-assembled urea-amine compound as vapor phase corrosion inhibitor for mild steel. Surface and Coatings Technology, 204, 1646-1650.

2. Nazeera Banu, V.R., Rajendran, S.S., \& Senthil, K. (2016). Investigation of the inhibitive effect of Tween 20 self-assembling nanofilms on corrosion of carbon steel. Journal of Alloys and Compounds, 675, 139-148.

3. Yujie, Q., Shulei, F., Shengtao, Z., Shijin, C., \& Xuefeng, Z. (2018). Designing and fabricating of single and double alkyl-chain indazole derivatives self-assembled monolayer for corrosion inhibition of copper. Corrosion Science, 140, 111121.

4. Hosseinpoura, S., Göthelidb, M., Leygrafa, C., \& Magnus, J. C. (2014). Self-assembled monolayers as inhibitors for the atmospheric corrosion of copper induced by formic acid: a comparison between hexanethiol and hexaneselenol. Journal of the Electrochemical Society, 161(1), 50-56.

5. Feng-ling, X., Jia-dong, Yang, Ri, Q., Jian, H., Ji-yong, Z., Jin-wei, Z. ... Cun-guo, L. (2016). Thiol self-assemble layer as inhibitor to protect B10 from seawater corrosion. Progress in Organic Coatings, 97, 82-90. Retrieved from https://doi.org/ 10.1016/j.porgcoat.2016.03.022.

6. Chyhyrynets', O. E., \& Vorob'iova, V. I. (2013). Anticorrosion Properties of the Extract of Rapeseed Oil Cake as a Volatile Inhibitor of the Atmospheric Corrosion of Steel. Materials Science, 49 (3), 318-325.

7. Chyhyrynets, O. E, Halchenko, H. Yu., Vorobiova, V. I., Pylypenko, T. M., \& Lipatov, S. Yu. (2012). Protykoroziini vlastyvosti shyshok khmeliu. Naukovi visti "KPI", (2), 137-148.

8. Vorobiova, V. I., Shakun, A. S., Trus, I. M., Tkachuk, V. M., Serdiu,k O. O., \& Chyhyrynets, O. 
E. (2018). Vyvchennia komponentnoho skladu ta protykoroziinoi efektyvnosti produktiv pererobky abrykosa (PrunusarmeniacaL.). Tekhnichni nauky ta tekhnolohii, 3(13), 240-250.

9. Roussos, P. A., Sefferou, V., Denaxa, N. K., Tsantili, E., \& Stathis, V. (2011). Apricot (Prunusarmeniaca L.) fruitquality attributes and phytochemical sunder different cropload. Scientiahorticulturae, 129, 472.

10. Gokbulut, I., \& Karabulut, I. (2012). SPME-GC-MS detection of volatile compounds in apricot varieties. FoodChemistry, 132, 1098.

11. Rajendran, S., Rathish, R. J., \& Prabha, S. S. (2017). Self-assembling nano films on metal surface as corrosion inhibitors. Advanced Materials Proceedings, 2(9), 596-601.

12. Shubha, H.N., Venkatesha, T.V., Pavithra, M.K., \& Punith Kumar, M.K. (2016). Surface modification of mild steel by a self-assembled cetyltrimethyl ammonium bromide (CTAB) monolayer: Evaluation of its corrosion protection property. Progress in Organic Coatings, 90, 267-276.

Цель. Разработка экологически безопасного летучего ингибитора для защиты от атмосферной коррозии углеродистой стали на основе растительных отходов, а именно выжимок промышленной переработки абрикоса.

Методика. Противокоррозионная эффективность летучих фракиий ингибитора оценена методами ускоренных коррозионных испытаний. Морфология и толщина образованных пленок изучена с помощью сканирующей атомно-силовой микроскопии.

Результаты. Установлено, что высокозащитная пленка летучих органических соединений выжимок абрикоса толщиной до $250 \mathrm{нм}$ формируется не менее 48 часов, обеспечивая торможение анодной и катодной реакций коррозии в условиях периодической конденсации влаги. В оптимальной конщентрации летучих соединений обеспечивается полная защита металла от коррозии.

Научная новизна. Показано, что выжимки промышленной переработки абрикоса является сырьем для создания эффективного экологически безопасного ингибитора для временной защиты металлопроката от атмосферной коррозии. Установлены особенности проиесса формирования защитной пленки и ее толщина.
Практическая значимость. Результаты свидетельствуют об эффективности использования упаковочных материалов с летучими ингибиторами на основе растительных отходов (выжсимок абрикоса) для использования производителями металлопроката с иелью повышения конкурентоспособности металлопродукиии.

Ключевые слова: летучий ингибитор атмосферной коррозии, временная защита от коррозии, наноразмерная пленка, растительные отходы.

Purpose. To develop an environmentally friendly volatile inhibitor for the protection of atmospheric corrosion of carbon steel based on vegetable wastes, namely, pomace of industrial processing of apricot.

Methodology. The corrosion resistance of volatile fractions of the inhibitor was evaluated by accelerated corrosion tests. The morphology and thickness of the formed films were studied by scanning atomic force microscopy.

Results. It is established that a highly protective film of volatile organic compounds of apricot shoots with a thickness of up to $250 \mathrm{~nm}$ is formed not less than 48 hours, providing inhibition of anodic and cathodic corrosion reactions under conditions of periodic moisture condensation. The optimum concentration of volatile compounds provides complete protection of the metal against corrosion.

Originality. It has been shown that the pomace of industrial apricot processing are the raw material for the creation of an effective environmentally friendly inhibitor for the temporary protection of rolled metal from atmospheric corrosion. The features of the process of forming the protective film and its thickness are determined.

Practical value. The results indicate the effectiveness of the use of packaging materials with volatile inhibitors based on vegetable waste (pomace apricot) for use by metal rolling manufacturer to improve the competitiveness metal products.

Keywords: volatile atmospheric corrosion inhibitor, temporary corrosion protection, nanoscale, vegetable waste.

Рукопис надійшов 12.07.2019 